\title{
Erratum to: Modeling the effects of ore properties on water recovery in the thickening process
}

Majid Unesi ${ }^{1)}$, Mohammad Noaparast ${ }^{2)}$, Seiyd Ziaedin Shafaei ${ }^{2)}$, and Esmaeil Jorjani ${ }^{1)}$

1) Department of Mining Engineering, Tehran Science and Research branch of Islamic Azad University, Tehran 1477893855, Iran

2) School of Mining Engineering, University of Tehran, Tehran 115554563, Iran

Erratum to: International Journal of Minerals, Metallurgy and Materials

Volume 21, Number 9, September 2014, Page 851

DOI: 10.1007/s12613-014-0981-y

The original version of this article unfortunately contained a mistake. The presentation of the affiliation was incorrect. The correct version is given below:

Department of Mining Engineering, Science and Research branch, Islamic Azad University, Tehran 1477893855, Iran

The online version of the original article can be found at http://dx.doi.org/10.1007/s12613-014-0981-y 